\title{
Inbreeding and inbreeding depression of Paeonia decomposita (Paeoniaceae), a threatened endemic plant to China
}

\author{
Shi-Quan Wang *
}

\begin{abstract}
Background: Small populations are predominantly vulnerable to inbreeding and inbreeding depression (ID). Owing to increased levels of inbreeding on individuals in small populations, ID could decrease the population growth rate, as well as its effective size, and exacerbate the extinction risk. Inbreeding depression remains a crucial area of research in conservation biology, ecology, and evolutionary biology. This study aims to elucidate the reproductive biology, inbreeding, and ID of Paeonia decomposita and to conserve, manage, and improve them better in the future.

Results: Paeonia decomposita belongs to a xenogamous category and is partially self-compatible; moreover, it requires pollinators for seed production. Lately, the occurrence of pollination and pollinator limitations has affected the seed set. Low seed set primarily correlated with an abnormality of meiosis in the pollen mother cell, moderate to low genetic diversity, drought and extreme weather, pollinator limitation, or carpel space limit. One of the primary reasons for endangered mechanism in P. decomposita is the low seed set under natural conditions. The cumulative value of ID was positive, and outcrossed progeny outperformed selfed progeny.

Conclusions: Paeonia decomposita requires pollinators to ensure seed production either through autogamy, geitonogamy, or allogamy. It is both allogamous and partially self-compatible, as well as a successful outcrosser. Inbreeding occurs frequently and results in ID, which imposes a potential threat to the survival of populations. Besides, it needs conservation via in situ and natural return methods.
\end{abstract}

Keywords: Paeonia decomposita, Reproductive biology, Conservation, Inbreeding, Inbreeding depression, Seed set

\section{Background}

Paeonia L. (Paeoniaceae) is a genus of 32 shrubbery and perennial herbs, mainly distributed in the northern hemisphere. The three sections in Paeonia include Section Onaepia, Section Moutan, and Section Paeonia (Hong 2010). Section Moutan comprises eight species, which are native and endemic to China (Hong 2010). Seed oil can be extracted from peony seeds, which contain fatty acid compositions, making them crucial woody oil crops at present (Zhang et al. 2015).

Paeonia seeds are big and mostly dispersed by gravity; thus, the transmission distance is very short. Besides, the pollen spread distance is very close (Luo et al. 1998;

*Correspondence: wsqmah@163.com

Ministry of Education Key Laboratory for Ecology of Tropical Islands, College of Life Sciences, Hainan Normal University, Haikou 571158, China
Hu et al. 2011). The distribution of individuals in natural habitat is gathered-type, and the number of individuals is low. The closer the distance, the higher the probability of successful pollination. However, the short distance of pollination and seed dispersion could result in close relative parents participating in mating. By the close offspring's genetic distance, these individuals form a family in a population (Hu et al. 2011). Furthermore, long-term inbreeding would certainly result in homozygous genotype and the population will be prone to inbreeding depression (ID).

Typically, inbreeding (i.e., mating between relatives) decreases the fitness/vigor of progenies. To some extent, inbreeding could be detrimental to populations in a short time (Keller and Waller 2002; Charlesworth and Willis 2009). ID is explained through two famous 
hypotheses-partial dominance hypothesis and overdominance hypothesis (Charlesworth and Charlesworth 1987; Culley et al. 1999; Charlesworth and Willis 2009). To date, several empirical studies have shown that the majority of ID resulted from harmful recessive or partly recessive alleles, which are demonstrated in homozygosity of inbred individuals (Charlesworth and Charlesworth 1987; Crow 1993; Latter et al. 1995; Willis 1999; Charlesworth and Willis 2009). Some of the recessive alleles could be fatal in homozygosity, while a large part seems to be non-lethal alleles.

ID, the decline in survival and fertility of descendants in closely related individuals, was promptly recognized as the main hindrance to the evolution of autogamy (Darwin 1876; Charlesworth and Charlesworth 1987). ID is detrimental to plants, which has been evidenced by seed abortion, low germination rates, high seedling fatality, poor growth, and anthesis in descendants (Dudash and Fenster 2000; Oostermeijer et al. 2003; Vere et al. 2008). Furthermore, ID might occur at any phase of growth and development.

In small populations, as all partners are close relatives, they are, in particular, susceptible to inbreeding and ID (Keller and Waller 2002). As a consequence of increased inbreeding depression, small populations could be subjected to retarded growth rate, decreased population sizes, and even extinction (Hedrick and Kalinowski 2000; Keller and Waller 2002; Frankham 2005; O'Grady et al. 2006). Although biologists have been interested in ID since 1876 (Darwin, 1876), it remains active in conservation, pollination, and evolution.

Paeonia decomposita Handel-Mazzetti is one species of Section Moutan. In history, $P$. decomposita contained two subspecies $-P$. decomposita subsp rotundiloba and $P$. decomposita subsp decomposita (Hong 1997, 2010; Hong and Pan 1999; Hong et al. 2001); after extensive morphological studies and systematic analyses, both were raised as independent species (Hong 2011). As a shrub, $P$. decomposita can reach a height of $180 \mathrm{~cm}$. Its seeds are black, glossy, broadly ellipsoid or globose, large and non-fleshy without specialized dissemination structure, making it not readily dispersed by birds and, thus, the spreading distance is very short.

Paeonia decomposita is endemic to China, distributed in the northwest of Sichuan Province, with sporadic and restricted distributions. The species has been recognized as a crucial woody oil crop, ornamental plant, and medicinal plant (its root-bark can be used as medicine, which is named "Danpi"). In addition, the population size is small and seedling recruitment is scant, making the species potentially apt to extinction. Based on the distribution, biological characteristics, and survival status, $P$. decomposita is an endangered (EN) plant in a threatened state (Hong et al. 2017).

Previously, some studies on reproductive biology have investigated some species of Paeonia, mainly concentrating on flora characteristics (Li et al. 2013; Yang et al. 2015), pollination (Grant 1964; Turpin and Schlising 1971; Schlising 1976; Luo et al. 1998; Zhou et al. 1999; Hong and Liu 2006; Li et al. 2014; Yang et al. 2015), breeding system (Li et al. 2013, 2014; Yang et al. 2015), pollinating insects behavior (Turpin and Schlising 1971; Schlising 1976; Luo et al. 1998; Li et al. 2014; Yang et al. 2015). Based on the related literature, this study adopts more comprehensive pollination treatments to measure self-compatibility and self-fertilization indices, percentage of pollinator limitation (PL) and pollination limitation (PPL), and ID. We performed one-sample $t$ test to assess the effects of different pollination treatments, regression analysis, and correlation analysis. Currently, understanding of the reproductive biology, inbreeding, and ID of $P$. decomposita remains inadequate. Considering the great value in medicine, ornament, industry, and highly narrow distribution, this study aims to comprehensively investigate the reproductive biology, inbreeding, and ID to conserve, manage, and improve them better in the future.

\section{Methods \\ Study site}

The fieldwork was conducted from April to June 2017 in a fragmented forest near the suburb of Maerkang county of Sichuan Province, China $\left(31^{\circ} 52^{\prime} 46.945^{\prime \prime}-31^{\circ} 52^{\prime}\right.$ $54.368^{\prime \prime} \mathrm{N}, 102^{\circ} 15^{\prime} 23.728^{\prime \prime}-102^{\circ} 15^{\prime} 27.896^{\prime \prime}$ E; $2700 \mathrm{~m}$ a.s.l.), where a large population of $P$. decomposita exists. In 2004, the population was much bigger than that now and the habitat was intact. With the time lapse, the natural habitats have been profoundly modified because of human activities such as fire, grazing, overly excavation, buildings, construction of hydroelectric power projects, and abusive specimen collection.

\section{Flowering phenology}

Some plants of $P$. decomposita $(n=22)$ were arbitrarily marked before flowering to assess the flowering phenology. Then, we checked the flowering process of the population until opening the last flower of the last labeled plant. Then, the flowering individual's percentage for each assessing day was calculated by dividing the number of marked plants with open flowers by the overall number of marked plants.

Flowering duration, pollen viability, and stigma receptivity In this study, 10 individuals were randomly selected and marked with a tag. Then, to calculate the flowering 
duration, two flowers on every tagged individual were marked before anthesis and observed until wilting daily. Then, floral buds from tagged individuals were bagged before flowering to avoid successive contamination of cross-pollen from the anthers to study the variation of pollen viability. All the flowers were packed in mesh bags, with $0.5 \mathrm{~mm} \times 0.5 \mathrm{~mm}$ mesh, to prevent flower visiting without affecting the flower development. We harvested the pollens of 1-7 days after anthesis from different flowers. To evaluate the percentage of pollen viability, we used the $\mathrm{I}_{2}-\mathrm{KI}$ test ( $\mathrm{Li} 2000$ ) by counting $>500$ pollen grains from nine individuals under a microscope $(400 \times)$. Furthermore, stigma receptivity was determined using the $\mathrm{H}_{2} \mathrm{O}_{2}$ method (Dafni 1992).

\section{Pollen-ovule ratio}

Mature buds were gathered just before anthesis and preserved in FAA to approximate overall pollen grains per flower. A specimen of the determined volume was located in a hemocytometer, in which the pollen grains were counted under a CX31 Olympus optical microscope $(100 \times)$ and this magnitude was used to extrapolate the overall number of pollen grains per flower. The ovary was cut apart with a scalpel and the ovules were quantified by a stereomicroscope $(120 \times)$. The pollen-ovule ratio $(\mathrm{P} / \mathrm{O})$ was evaluated by dividing the pollen grain number by ovule number per flower, as described by Cruden (1977).

\section{Pollination treatments}

Pollination treatment was performed on randomly selected separate trees of $P$. decomposita. We used eight pollination treatment groups to determine the mating system and ID. Individual pollination treatment was performed on 40-80 flowers as follows: (1) natural pollination (control) - the flower buds were marked and left intact for open pollinating; (2) bagging without emasculation-the flower buds were marked and packed to investigate the autogamy ("autogamic pollination"); (3) bagging with emasculation - the flower buds were emasculated, marked, and packed to assess the apomixis; (4) bagging with mesh bag after emasculation-the flower buds were emasculated, marked, and packed with mesh bags to assess anemophily; (5) artificial geitonogamyemasculated flowers were packed and pollinated with pollen of the flowers of the same shrub to measure the self-compatibility and potential ID; (6) artificial xenogamy-emasculated flowers were bagged and pollinated with pollen of the flowers of various plants $>10 \mathrm{~m}$ away; (7) emasculation without bagging-the flower buds were emasculated, labeled, and unbagged, exposed to pollinators, freely pollinated to detect efficiency of cross-pollination, outcrossing rates, and pollinator limitation levels; (8) hand supplemental pollination-unbagged flowers were handily pollinated with pollen of the flowers of dissimilar plants $>10 \mathrm{~m}$ away.

The emasculation manipulations were conducted before anthesis, and pollinations were performed when stigmas were receptive by brushing pollen over the stigmas until their surface was saturated. The bags were eliminated when withering the flowers to diminish the impact of bagging on fruit formation. When the follicle ripened and did not crack in autumn, fruits were harvested separately according to different treatments and placed in paper bags to allow fruits to break naturally. Next, the impact of each treatment was assessed according to the fruit set (ratio of fruits to treated flowers), seed set (ratio of seeds to the number of ovules), seed weight (g/1000 grain), percentage of carpels for seed set, number of seeds/fruit, and number of seeds/carpel.

\section{Related indices}

We determined various indicators associated with the mating system using the findings achieved from handpollinating tests.

\section{Self-compatibility and self-fertilization indices}

Using those all apparently well-developed seeds, selffertilization index (SFI) and self-compatibility index (SCI) were determined, as described by Lloyd and Schoen (1992). SCI is the seed set ratio between self-pollinated flowers and cross-pollinated flowers. SFI provides an approximation of a plant's capacity to produce seeds with no pollen vector. SFI is the seed set ratio between spontaneous self-pollination flowers and cross-pollinated flowers.

\section{Percentage of pollinator limitation (PL)}

The degree of reproductive accomplishment restriction by an inadequate pollinator was evaluated using the following formula:

$$
P L=\left[\left(P_{X}-P_{E}\right) \times 100\right] / P_{X}
$$

where $P_{X}$ denotes the seed set of outcross-pollinated flower, and $P_{E}$ denotes the seed set of the outcross-pollinated flower of emasculation without a bag (Castro et al. 2008).

\section{Percentage of pollination limitation (PPL)}

The degree of procreative accomplishment restriction by inadequate pollen delivery was defined as follows:

$$
P P L=[100 \times(P S-C)] / P S
$$

where $P S$ denotes for the seed set of pollen supplemental plants, and $C$ represents the seed set of control plants (Jules and Rathcke 1999). 


\section{Inbreeding depression}

The value of ID $(\delta)$ was calculated from four reproductive traits (number of seeds per fruit, fruit set, seed set, and weight of seed), as described by Charlesworth and Charlesworth' method (1987), as follows:

$$
\begin{aligned}
& \delta=1-W_{\mathrm{s}} / W_{\mathrm{o}}, \quad \text { when } W_{\mathrm{s}} \leq W_{\mathrm{o}} ; \\
& \quad \text { or } \delta=W_{\mathrm{s}} / W_{\mathrm{o}}-1, \quad \text { when } W_{\mathrm{s}} \geq W_{\mathrm{o}}
\end{aligned}
$$

where $W_{\mathrm{s}}$ denotes the average fitness of selfed progeny from hand self-pollination; $W_{\mathrm{o}}$ denotes the average fitness of manually outcrossed progeny from hand crosspollination (Schemske and Lande 1985; Charlesworth and Charlesworth 1987).

The accumulative value of ID with the correlation among the data of the four parameters was calculated for the fitness ratio set of the four procreative features (fruit set, seed set, seeds per fruit, and seed weight). The seed germination was not included in measuring and evaluating the accumulative fitness in the present study, due mainly to the seed dormancy which was investigated pervasively in Section Moutan (Jing and Zheng 1999).

As described by Husband and Schemske (1996), we used the following formula:

$$
\begin{aligned}
\delta= & 1-\left[W \mathrm{~s}_{\mathrm{f}} / W \mathrm{o}_{\mathrm{f}} \times W \mathrm{~s}_{\mathrm{sf}} / W \mathrm{o}_{\mathrm{sf}}\right. \\
& \left.\times W \mathrm{~s}_{\mathrm{s}} / W \mathrm{o}_{\mathrm{s}} \times W \mathrm{~s}_{\mathrm{sw}} / W \mathrm{o}_{\mathrm{sw}}\right]
\end{aligned}
$$

where $\mathrm{f}$ is fruit set; $\mathrm{sf}$ is seeds per fruit; $\mathrm{s}$ is seed set; and sw is seed weight.

The values of ID range from -1 to 1 , where 0 signifies no ID, and positive values indicate the outcrossed offspring outperforming selfed offspring (ID), whereas the negative values simply the reverse style (Charlesworth and Charlesworth 1987).

\section{Statistical analyses}

We calculated descriptive statistics for the $\mathrm{P} / \mathrm{O}$ ratio, pollen viability, seed set, fruit set, and seed weight. All the analyses were performed using the program package SPSS 17 (SPSS Inc. Chicago, Illinois, USA) and Excel. In addition, we performed a one-sample $t$-test to assess the effects of different pollination treatments, using regression analysis and correlation analysis among seed weight, seed set (\%), percentage of carpels for seed set, fruit set (\%), number of seeds/fruit, number of seeds/carpel.

\section{Results}

\section{Flowering phenology}

Flowers opened sequentially from mid-April to late May each year; flowering duration of the population lasted for $\geq 43$ days, and marginal differences were present between different years because of climate change. During the flowering period, a short blooming peak in late April existed, with $>50 \%$ of sampled plants in bloom.

\section{Floral lifespan, pollen viability, and stigma receptivity}

A single flower was still open for some days up to felling off the stamens and corolla. The mean floral lifespan of a single flower was 7.75 days ( $n=40$ flowers). The anther dehiscence began occurring on the first day of the opening, and the average pollen viability was much higher $(79.67 \% \pm 1.61 \% ; 1-7$ after flowering). The viability reached a maximum $(87.00 \% \pm 1.12 \%)$ on the fourth day after blooming. While stigma was generally receptive on the second day after anthesis, it was rather weak and lasted for nearly 7 days.

\section{Pollen-ovule ratio}

On average, $P$. decomposita flower produces 184,292,308 pollen grains and 73 ovules per flower. The $\mathrm{P} / \mathrm{O}$ was 2,011,311 based on the category of Cruden (1977); (the ratio was calculated excluding the inviable pollen grains), the mating system of this species associated with the xenogamy class.

\section{Pollination treatment experiments One-sample t-test}

The $t$ value of the one-sample $t$-test with SPSS in the seed weight, seed set (\%), percentage of carpels for the seed set, number of seeds/fruit, number of seeds/carpel, and fruit set (\%) were 4.259, 2.942, 3.575, 3.415, 3.991, and 4.087, respectively, and all the differences were significant $(P<0.05$; Table 1$)$.

\section{Effects of different pollination treatments}

Table 2 presents detailed results of different pollination treatments. The pollen source markedly affected the seed set and fruit set, and no seed production was observed after bagging with emasculation and mesh bag with emasculation; this suggests that $P$. decomposita flowers were not able to apomixis and anemophily and, thus, relied on pollen transmission vectors to effective pollinating. The seed set and fruit set in bagging without emasculation (autogamy; $8.51 \%$ and 55\%, respectively) and artificial geitonogamy $(5.60 \%$ and $61.35 \%$, respectively) were all low and similar, with no significant difference $(P<0.05)$, revealing a lack of a dichogamous system preventing the facilitated self-fertilization. In addition, artificial xenogamy and hand supplemental pollination treatment led to a higher fruit set $(100 \%$ and $100 \%$, respectively) and seed set $(25.32 \%$ and $29.11 \%$, respectively) compared with those in the bagging protection (Fig. 1). We noted no considerable difference in the average seed set among 
Table 1 One-sample $t$ test in seed weight (g/1000 grain), seed set (\%), percentage of carpels for seed set, number of seeds/fruit, fruit set (\%) and number of seeds/carpel in P. decomposita

\begin{tabular}{|c|c|c|c|c|c|c|}
\hline \multirow[t]{2}{*}{ Traits } & \multirow[t]{2}{*}{$\mathbf{T}$} & \multirow[t]{2}{*}{ df } & \multirow[t]{2}{*}{ Sig. (2-tailed) } & \multirow[t]{2}{*}{ Mean difference } & \multicolumn{2}{|c|}{$\begin{array}{l}95 \% \text { confidence interval } \\
\text { of the difference }\end{array}$} \\
\hline & & & & & Lower & Upper \\
\hline Seed weight (g/1000 grain) & 4.259 & 7 & 0.004 & 242.9088 & 108.0373 & 377.7802 \\
\hline Seed set (\%) & 2.942 & 7 & 0.022 & 13.0563 & 2.5622 & 23.5503 \\
\hline Percentage of carpels for seed set & 3.575 & 7 & 0.009 & 49.3550 & 16.7131 & 81.9969 \\
\hline Number of seeds/fruit & 3.416 & 7 & 0.011 & 7.6500 & 2.3540 & 12.9460 \\
\hline Fruit set (\%) & 4.087 & 7 & 0.005 & 59.6825 & 25.1497 & 94.2153 \\
\hline Number of seeds/carpel & 3.991 & 7 & 0.005 & 2.6538 & 1.0815 & 4.2260 \\
\hline
\end{tabular}

Table 2 Effects of different pollination treatments (mean \pm SE) on several traits in P. decomposita

\begin{tabular}{|c|c|c|c|c|c|c|c|}
\hline S. no. & $\begin{array}{l}\text { Pollination } \\
\text { treatments }\end{array}$ & $\begin{array}{l}\text { Seed weight } \\
\text { (g/1000 grain) }\end{array}$ & Seed set (\%) & $\begin{array}{l}\text { Percentage } \\
\text { of carpels } \\
\text { for seed set }\end{array}$ & $\begin{array}{l}\text { Number of seeds/ } \\
\text { fruit }\end{array}$ & Fruit set (\%) & $\begin{array}{l}\text { Number of seeds/ } \\
\text { carpel }\end{array}$ \\
\hline 1 & Natural pollination & $290.03 \pm 35.63^{b c}$ & $28.67 \pm 0.59^{c}$ & $91.48 \pm 3.57^{c}$ & $15.46 \pm 0.88^{c}$ & $98.89 \pm 1.11^{c}$ & $4.62 \pm 0.23^{c}$ \\
\hline 2 & $\begin{array}{l}\text { Bagging without } \\
\text { emasculation }\end{array}$ & $199.19 \pm 80.74^{b}$ & $8.51 \pm 3.22^{b}$ & $34.00 \pm 12.61^{b}$ & $4.30 \pm 1.71^{b}$ & $55.00 \pm 10.41^{b}$ & $3.90 \pm 2.11^{b c}$ \\
\hline 3 & $\begin{array}{l}\text { Bagging with emas- } \\
\text { culation }\end{array}$ & $0.00 \pm 0.00^{\mathrm{a}}$ & $0.00 \pm 0.00^{\mathrm{a}}$ & $0.00 \pm 0.00^{\mathrm{a}}$ & $0.00 \pm 0.00^{\mathrm{a}}$ & $0.00 \pm 0.00^{\mathrm{a}}$ & $0.00 \pm 0.00^{\mathrm{a}}$ \\
\hline 4 & $\begin{array}{l}\text { Mesh bag with emas- } \\
\text { culation }\end{array}$ & $0.00 \pm 0.00^{\mathrm{a}}$ & $0.00 \pm 0.00^{\mathrm{a}}$ & $0.00 \pm 0.00^{\mathrm{a}}$ & $0.00 \pm 0.00^{\mathrm{a}}$ & $0.00 \pm 0.00^{\mathrm{a}}$ & $0.00 \pm 0.00^{\mathrm{a}}$ \\
\hline 5 & $\begin{array}{l}\text { Artificial geito- } \\
\text { nogamy }\end{array}$ & $365.62 \pm 15.38^{c}$ & $5.60 \pm 2.2^{\mathrm{ab}}$ & $41.33 \pm 12.16^{b}$ & $5.73 \pm 1.33^{b}$ & $61.35 \pm 9.40^{b}$ & $1.94 \pm 0.17^{\mathrm{ab}}$ \\
\hline 6 & Artificial xenogamy & $390.51 \pm 23.16^{c}$ & $25.32 \pm 0.43^{c}$ & $84.26 \pm 4.05^{c}$ & $14.47 \pm 1.34^{c}$ & $100 \pm 0.00^{c}$ & $4.35 \pm 0.30^{b c}$ \\
\hline 7 & $\begin{array}{l}\text { Emasculation with- } \\
\text { out bag }\end{array}$ & $367.70 \pm 60.56^{c}$ & $7.24 \pm 2.27^{b}$ & $44.58 \pm 7.67^{b}$ & $7.17 \pm 1.64^{b}$ & $62.22 \pm 2.22^{b}$ & $2.42 \pm 0.35^{a b c}$ \\
\hline 8 & $\begin{array}{l}\text { Hand supplemental } \\
\text { pollination }\end{array}$ & $330.22 \pm 6.56^{c}$ & $29.11 \pm 4.11^{c}$ & $99.19 \pm 0.81^{c}$ & $14.07 \pm 1.66^{c}$ & $100 \pm 0.00^{c}$ & $4.00 \pm 0.54^{b c}$ \\
\hline
\end{tabular}

Different lowercase letters in the same column indicate significant differences among pollination treatments $(P<0.05)$

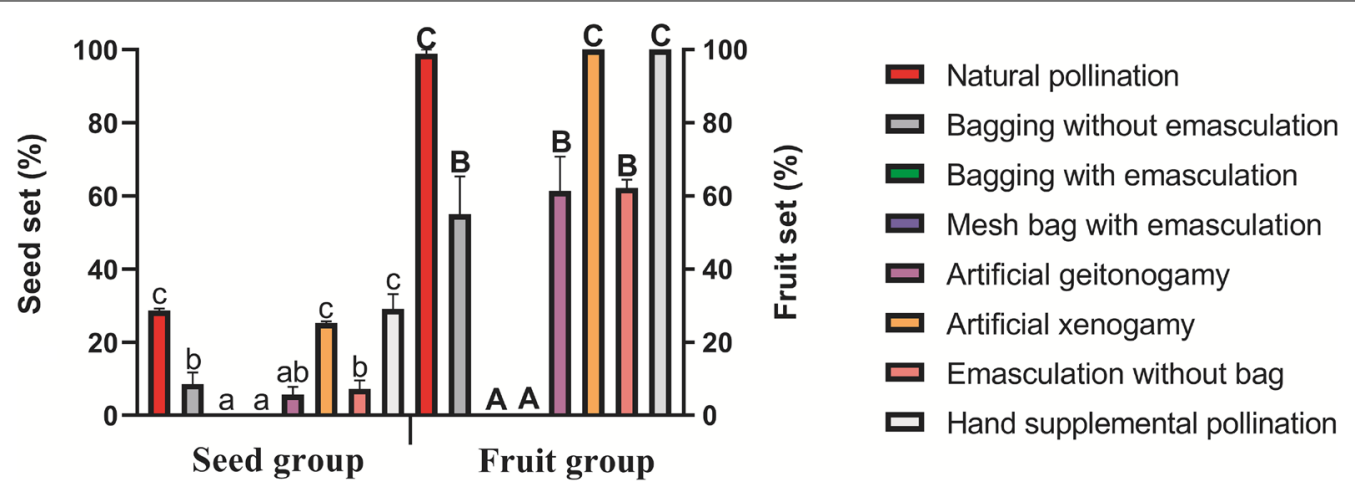

Fig. 1 Seed set (\%) and fruit set (\%) of different pollination treatments in P. decomposita. Bars are means and vertical lines above bars are standard errors. The significant difference of seed set and fruit set were indicated in lowercase and bold capital, respectively

natural pollination, artificial xenogamy, and hand supplemental pollination; however, a markedly significant difference existed in the seed set between artificial geitonogamy, emasculation without bag, bagging without emasculation and natural pollination, artificial xenogamy, and hand supplemental pollination.

A majority of artificial geitonogamous flowers set were very few or without seeds, with an average of 5.73 seeds 
per fruit and 1.94 seeds per carpel (Table 2; Fig. 2a). Compared with the other treatments, the number of seeds per fruit and per carpel was relatively higher in artificial xenogamous (Fig. 2b), hand supplemental pollination flowers, as well as in natural pollination individuals (control plants). Moreover, we noted a significant difference in the number of seeds per fruit and percentage of carpels for seed set between artificial geitonogamy and artificial xenogamous, hand supplemental pollination flowers, and natural pollination individuals.

Regarding the seed weight, a significant difference was noted between bagging without emasculation and artificial geitonogamy, artificial xenogamy, emasculation without bag, and hand supplemental pollination (Table 2).

\section{Correlation analysis}

For six indices (seed weight, seed set, percentage of carpels for seed set, number of seeds per fruit, fruit set, and number of seeds per carpel), we observed a significant correlation $(P<0.05)$ between seed weight and percentage of carpels for seed set $(R=0.784)$, number of seeds/fruit $(R=0.769)$, and number of seeds per carpel $(R=0.743)$; a high correlation was observed between the seed weight and the fruit set $(R=0.880 ; P=0.004)$. In addition, a really considerable relationship was noted at the 0.01 level between the seed set and the percentage of carpels for seed set, number of seeds/fruit, fruit set, number of seeds per carpel. Besides, no significant correlation was found between the seed set and the seed weight. Of note, we observed an extremely significant correlation at the level of 0.01 among other indices (Table 3).

\section{Regression analysis}

The regression analysis formula was obtained as follows:

$$
Y=-0.518-0.027 X_{1}+1.576 X_{3}+0.136 X_{4},
$$

where $Y$ denotes the seed set (\%); $X_{1}$ denotes the seed weight; $X_{3}$ is the number of seeds/fruit; and $X_{4}$ is the fruit set (\%).

The main factors affecting the seed set are the number of seeds/fruit, seed weight, and fruit set (\%). The order of
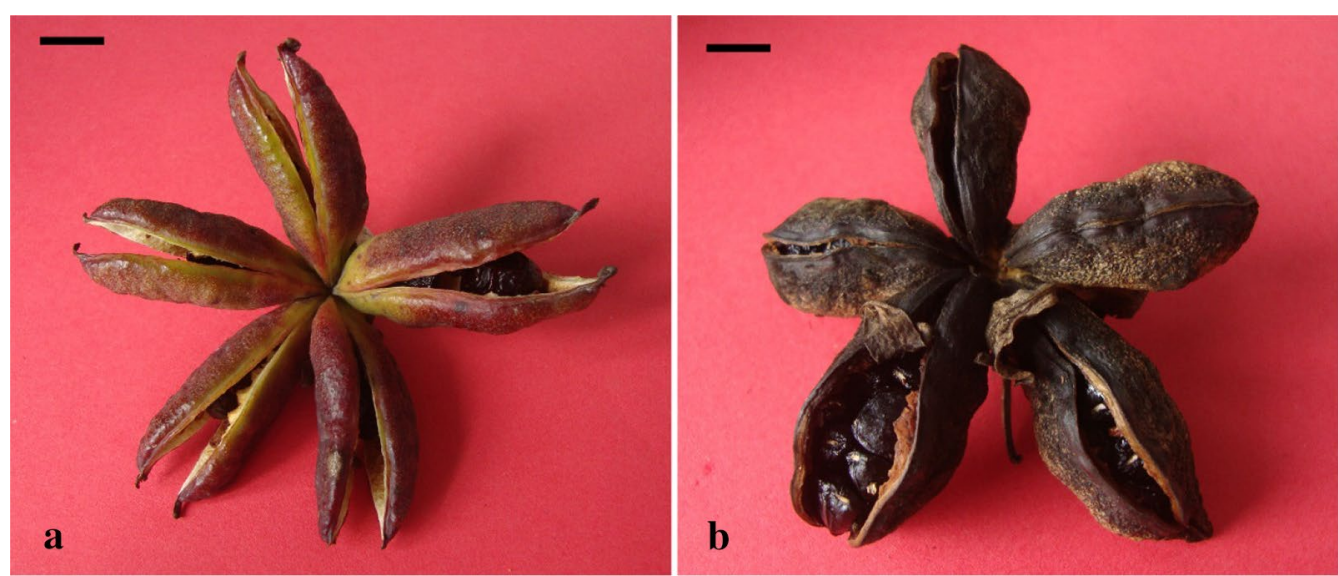

Fig. 2 Fruit and seeds. a Artificial geitonogamy; b Artificial xenogamy. Scale bar $=1 \mathrm{~cm}$

Table 3 Correlation analysis among seed weight (g/1000 grain), seed set, percentage of carpels for seed set, number of seeds/fruit, fruit set, number of seeds/carpel in P. decomposita

\begin{tabular}{|c|c|c|c|c|c|c|}
\hline index & $\begin{array}{l}\text { Seed weight } \\
\text { (g/1000 grain) }\end{array}$ & Seed set (\%) & $\begin{array}{l}\text { Percentage } \\
\text { of carpels for seed } \\
\text { set }\end{array}$ & $\begin{array}{l}\text { Number } \\
\text { of seeds/fruit }\end{array}$ & Fruit set (\%) & $\begin{array}{l}\text { Number } \\
\text { of seeds/ } \\
\text { carpel }\end{array}$ \\
\hline Seed weight (g/1000 grain) & - & & & & & \\
\hline Seed set $(\%)$ & 0.624 & - & & & & \\
\hline Percentage of carpels for seed set & $0.784^{a}$ & $0.971^{b}$ & - & & & \\
\hline Number of seeds/fruit & $0.769^{a}$ & $0.972^{b}$ & $0.988^{b}$ & - & & \\
\hline Fruit set $(\%)$ & $0.880^{b}$ & $0.911^{b}$ & $0.975^{b}$ & $0.963^{b}$ & - & \\
\hline Number of seeds/carpel & $0.743^{\mathrm{a}}$ & $0.868^{b}$ & $0.893^{b}$ & $0.881^{b}$ & $0.936^{b}$ & - \\
\hline
\end{tabular}

\footnotetext{
a Significant correlation at the 0.05 level

b Extremely significant correlation at the 0.01 level
} 
influence on the seed set $(Y)$ is the number of seeds/fruit, the weight of the seeds, and fruit set (\%).

\section{Self-compatibility and self-fertilization indices}

The SCI value was 0.22 , belonging to partial self-compatibility ( $\mathrm{SCI}=0.15-0.49$; Ferrer et al. 2009). The SFI value was 0.34 , over the threshold of 0.2 for self-compatibility (Lloyd and Schoen 1992).

\section{$P L$}

The fruit set $(62.22 \%)$ and seed set $(7.24 \%)$ of emasculation without bag were significantly lower than the artificial xenogamy treatment, suggesting the occurrence of pollinator limitation. Furthermore, a comparatively great pollinator limitation (71.41\%) supported this issue.

\section{PPL}

Under natural circumstances, the seed set (28.67\%) and fruit set $(98.89 \%)$ were marginally lower than the hand supplemental pollination treatment, revealing the incidence of pollen limitation; however, the difference was not significant $(P>0.05)$. Of note, this finding was supported by the PPL value (1.51\%).

\section{ID}

Based on the results of outcross pollination and self-pollination treatments in $P$. decomposita, the highest intensity of ID was obtained for the seed set $(\delta=0.78)$, marginally higher for seeds/fruit $(\delta=0.60)$, while relatively lower for fruit set $(\delta=0.39)$ and seed weight $(\delta=0.06)$ (Table 4$)$. In this study, the cumulative value of ID was 0.9497 . Furthermore, values $>0$ reveal the further fitness of the outcrossed progeny compared to selfed progeny.

\section{Discussion}

\section{Mating patterns}

The flowering duration of the population was between April 12 and May 24 in 2017. The flowering period of a single flower was usually between 6 and 9 days (average: 7.75 days). In plants, flowers are the only parts that directly attract the pollinator; thus, its functional and morphological features could affect the plant's procreative accomplishment. During the early flowering period, only a few other plants were in bloom, thereby guaranteeing pollinators' pollination on $P$. decomposita. The $\mathrm{P} / \mathrm{O}$ ratio suggests that $P$. decomposita is xenogamy, similar to P. delavayi (Li et al. 2013, 2014) and P. californica (Schlising 1976). The results of hand-pollination experiments, self-fertilization, and self-compatibility indices demonstrated that $P$. decomposita required pollinators' visitation to form seed, as there was no seed after pollinator exclusion (Table 2), which belonged to the xenogamous category, partial self-compatibility. These findings corroborated the type of predicted $\mathrm{P} / \mathrm{O}$ value. P. decomposita is not capable of apomixes and anemophily, and flowers advanced rewards (pollen) to attract the pollinators to transport their male gametes (Dafni et al. 2005).

\section{Seed set}

Pollen quality and availability were the two main factors of female reproductive accomplishment (Griffin and Barrett 2002). Pollination quality is determined by pollinators' behavior, which can be affected by plant density (Grindeland et al. 2005). Reportedly, pollinator limitation and pollen limitation are extensive, especially in species pollinated by animals (Ashman et al. 2004). Co-flowering plants could result in the competition of pollinators, incremented heterospecific pollen provision, and/ or stigma clogging by heterospecific pollen (Gross 1996). For $P$. decomposita's population, other species also starts flowering during its peak flowering duration, competing for latent pollinators, and decreasing the visitation rate to $P$. decomposita. In the treatment of emasculation without bag, the visit number and visit rate of insects markedly decreased because of removed and lost attraction to insects by stamen and petal. Thus, pollinator limitation occurred and resulted in a significantly lower seed set (7.24\%). In addition, hand supplemental pollination did not considerably increase seed production $(0.44 \%)$ compared with natural pollination. As the individual distribution of $P$. decomposita is sporadic and narrow in small and fragmented range, pollen resources for pollination could be restricted. In addition, the resource allocation and available resources play a vital role in the ultimate female reproductive success (Wesselingh 2007). Thus, the occurrence of pollination limitation and pollinator

Table 4 Fitness of selfed and outcrossed progeny, and inbreeding depression coefficient $(\delta)$ of different traits

\begin{tabular}{llcc}
\hline Plant traits & Outcrossed fitness & Selfed fitness & $\begin{array}{c}\text { Inbreeding depression } \\
\text { coefficient }(\boldsymbol{\delta})\end{array}$ \\
\hline Fruit set (\%) & 100 & 61.35 & 0.39 \\
Number of seeds/fruit & 14.47 & 5.73 & 0.60 \\
Seed set (\%) & 25.32 & 5.60 & 0.78 \\
Seed weight (g/1000 grain) & 390.51 & 365.62 & 0.06 \\
\hline
\end{tabular}


limitation during the pollination process affected the fruit set and seed set to some extent in this species.

The results of pollination revealed that $P$. decomposita could produce seed by self-pollination; however, the seed set was very low [only $5.60 \%$ in artificial geitonogamy, lower than that in Yang et al. (2015) study, 11.04\%; $8.51 \%$ in autogamy, higher than that in Yang et al. (2015) study, 4.06\%], which was significantly lower than artificial xenogamy $(25.32 \%)$, and the difference was significant $(P<0.05)$, suggesting the existence of an auto-incompatibility structure. The incidence of auto-incompatibility structure would enhance outcrossing and avoid ID (Silva and Goring 2001). While the seed set in artificial xenogamy [25.32\%, higher than that in Yang et al. (2015) study, 18.33\%] was lower than that in natural pollination [28.67\%, higher than that in Yang et al. (2015) study, $23.76 \%]$, and no considerable difference existed in their seed set $(P>0.05)$. Usually, seed set of natural pollination was very low $(<30 \%)$ in the studied species (Schlising 1976; Luo et al. 1998; Hong and Liu 2006; Yang et al. 2015; this study) of Paeonia genus, except for $P$. delavayi (77.8\%; Li et al. 2013, 2014).

While 4.62 mature seeds existed per carpel of natural pollination, 11.6 ovules per carpel could not fertilize and form seeds or abort in P. decomposita. However, there were 4.2 seeds per carpel in P. californica (Schlising 1976) and 2.1 seeds per carpel in P. jishanensis (Zhou et al. 1999). The low seed set in this species largely correlated with some factors, including the abnormality of meiosis in pollen mother cells (Wang and Zhang 2008), moderate genetic diversity (unpublished data), drought and extreme weather (continuous rain in 2017, drought in 2018), pollinator limitation, carpel space limit (Stebbins and Ellerton 1939; Walter 1942; Schlising 1976). The low seed set in natural condition was one of the main reasons for the endangered mechanism in $P$. decomposita.

\section{Inbreeding depression}

Inbreeding is not avoidable in small isolated populations (Frankham et al. 2003), and it is supposed to exacerbate the risk of extinction in endangered groups (Brook et al. 2002). Reportedly, levels of outcrossing are lower for plant populations in fragmented or disturbed environments compared with the undisturbed habitats (Ward et al. 2005; Coates et al. 2007). As inbreeding could be resulting from subdividing the population (Keller and Waller 2002), the population subdivision level is a factor leading to the difference in the inbreeding level. In this study, the impact of isolation and population size could not be assessed owing to the population delimitation subjectivity. Notably, the pollinators' foraging behavior is affected by the density of plant population (Field et al. 2005). Thus, the plants' spatial distribution in a population, perhaps, affects the outbreeding level via the pollinators' visitation arrangement.

To the best of our knowledge, this is the first study to investigate the inbreeding levels and extent of ID on an endangered species in the greatly fragmented forestry ecosystem in Paeonia. P. decomposita is prone to ID because reproduction happens between close relatives or by individual owns. The seed number was considerably lower in the self-pollination, suggesting that a high amount of unfit inbred progeny harboring deleterious alleles are already eliminated over-fertilizing or at the early seed development phase.

Based on the outcomes of self-pollination and outcross-pollination treatments, the ID value of four traits (seeds per fruit, fruit set, seed weight, and seed set) of $P$. decomposita was different. The accumulative value of ID was high and positive (0.9497) and outcrossed progeny outperformed selfed progeny.

\section{Conservation and management implications}

Lately, human activities have markedly influenced natural habitats of $P$. decomposita. Owing to important ornamental, medicinal, and oil value, local villagers excavate its roots and collect its seeds for personal benefits. Moreover, the massive excavation and collection make it more difficult to regenerate.

Inbreeding frequently occurs in $P$. decomposita and results in a considerable ID levels. In addition, inbreeding and ID are a latent risk to the survival of populations and, thus, should be considered in planning the conservation actions. It would be especially significant to investigate the necessity of genetic management, inbreeding levels, and the occurrence rate of ID in markedly endangered species in small forest fragments.

This study offers practical, useful, and valuable information to guide recovery efforts for $P$. decomposita populations. Executing an active program to restore this species is warranted, given the extensive habitat destruction of human activities in the past and the restricted size of the few remaining $P$. decomposita populations. Besides, restoration efforts are most probably to succeed in areas with a large population of plants, especially if populations contain plants gathered from a few existing sites.

Hence, conservation approaches for $P$. decomposita should focus on the following features: (1) local government should establish some small nature reserves to limit the exploitation and govern the damage to natural habitats and enhance the original habitats' recovery; (2) largescale cultivation should be carried out to cater to market demand and minimize damages to wild species; and (3) breeding technology should be improved and more saplings should be cultivated. In addition, they should be introduced back into the original habitats to increase the 
population density and offer more pollen sources. Perhaps, this study would provide a basis for better conservation, management, and improvement in the future.

\section{Conclusions}

Like most other Paeonia species, $P$. decomposita requires pollinators to ensure seed formation both via autogamy (pollinating a flower by its own pollen), geitonogamy (pollinating within flowers of the same plants), or allogamy (pollinating within flowers from various individuals), and appeared to be both allogamous and partial self-compatibility and, thus, a successful outcrosser. $P$. decomposita is not capable of apomixes and anemophily, and flowers attract pollinators by pollen. In addition, the number of seeds per carpel and seed set in this species is all low. Besides, inbreeding occurs frequently in $P$. decomposita and results in ID, creating a latent threat to the population survival requiring conservation via in situ and natural return methods.

\author{
Abbreviations \\ ID: inbreeding depression; P/O: pollen-ovule ratio; PL: percentage of pollina- \\ tor limitation; PPL: percentage of pollination limitation; SCl: self-compatibility \\ index; SFI: self-fertilization index.
}

\section{Acknowledgements}

I am grateful to the concerned local bodies in Maerkang for providing research permission in the forests. I thank Luosang Sidanzhen for his help in the field experiments.

\section{Authors' contributions}

S-QW conceived and designed the study, performed experiments, analyzed the data and wrote the paper. The author read and approved the final manuscript.

\section{Funding}

This study was supported by the National Natural Science Foundation of China (Grant Nos. 31670345, 31860085).

\section{Availability of data and materials}

The datasets used and/or analyzed during the current study are available from the corresponding author on reasonable request.

\section{Ethics approval and consent to participate Not applicable.}

\section{Consent for publication}

Not applicable.

\section{Competing interests}

The author declares there is no competing interests.

Received: 5 July 2019 Accepted: 20 November 2019 Published online: 05 December 2019

\section{References}

Ashman TL, Knight TM, Steets JA, Amarasekare P, Burd M, Campbell DR, Dudash MR, Johnston MO, Mazer SJ, Mitchell RJ, Morgan MT, Wilson WG (2004) Pollen limitation of plant reproduction: ecological and evolutionary causes and consequences. Ecology 85:2408-2421. https://doi. org/10.1890/03-8024
Brook BW, Tonkyn DW, O'Grady JJ, Frankham R (2002) Contribution of inbreeding to extinction risk in threatened species. Conserv Ecol 6:69-84. https:// doi.org/10.5751/ES-00387-060116

Castro S, Silveira P, Navarro L (2008) How flower biology and breeding system affect the reproductive success of the narrow endemic Polygala vayredae Costa (Polygalaceae). Bot J Linn Soc 157:67-81. https://doi.org/10.111 1/j.1095-8339.2008.00784.x

Charlesworth D, Charlesworth B (1987) Inbreeding depression and its evolutionary consequences. Annu Rev Ecol Syst 18:237-268. https://doi. org/10.1146/annurev.es.18.110187.001321

Charlesworth D, Willis JH (2009) The genetics of inbreeding depression. Nat Genet 10:783-798. https://doi.org/10.1038/nrg2664

Coates DJ, Sampson JF, Yates CJ (2007) Plant mating systems and assessing population persistence in fragmented landscapes. Aust J Bot 55:239-249. https://doi.org/10.1071/BT06142

Crow JF (1993) Mutation, mean fitness, and genetic load. Oxford Surv Evol Biol 9:3-42

Cruden RW (1977) Pollen-ovule ratio: a conservative indicator of breeding system in plants. Evolution 31:32-46. https://doi. org/10.1111/j.1558-5646.1977.tb00979.x

Culley TM, Weller SG, Sakai AK, Rankin AE (1999) Inbreeding depression and selfing rates in a self-compatible, hermaphroditic species, Schiedea membranacea (Caryophyllaceae). Am J Bot 86:980-987. https://doi. org/10.2307/2656615

Dafni A (1992) Pollination ecology: a practical approach. Oxford University Press, New York

Dafni A, Kevan PG, Husband BC (2005) Plant breeding systems and pollen dispersal. Practical pollination biology, 1st edn. Enviroquest Ltd, Cambridge

Darwin CR (1876) The effects of cross and self-fertilization in the vegetable kingdom. John Murray, London

Dudash MR, Fenster CB (2000) Inbreeding and outbreeding depression in fragmented populations. In: Young A, Clarke G (eds) Genetics, demography, and viability of fragmented populations. Cambridge University Press, Cambridge, pp 55-74

Ferrer MM, Good-Avila SV, Montana C, Domínguez CA, Eguiarte LE (2009) Effect of variation in self-incompatibility on pollen limitation and inbreeding depression in Flourensia cernua (Asteraceae) scrubs of contrasting density. Ann Bot 103:1077-1089. https://doi.org/10.1093/aob/mcp033

Field DL, Ayre DJ, Whelan RJ (2005) The effect of local plant density on pollinator behavior and the breeding system of Persoonia bargoensis (Proteaceae). Int J Plant Sci 166:969-977. https://doi.org/10.1086/467473

Frankham R (2005) Genetics and extinction. Biol Conserv 126:131-140. https:// doi.org/10.1016/j.biocon.2005.05.002

Frankham R, Ballou JD, Briscoe DA (2003) Introduction to conservation genetics. Cambridge University Press, Cambridge

Grant V (1964) The architecture of the germplasm. Wiley, New York

Griffin SR, Barrett SCH (2002) Factors affecting low seed: ovule ratios in a spring woodland herb, Trillium grandiflorum (Melanthiaceae). Int J Plant Sci 163:581-590. https://doi.org/10.1086/340814

Grindeland JM, Sletvold N, Ims RA (2005) Effects of floral display size and plant density on pollinator visitation rate in a natural population of Digitalis purpurea. Funct Ecol 19:383-390. https://doi.org/10.111 1/j.1365-2435.2005.00988.x

Gross CL (1996) Is resource overlap disadvantageous to three sympatric legumes? Aust J Eco 21:133-143. https://doi.org/10.1111/j.1442-9993.1996. tb00594.x

Hedrick PW, Kalinowski ST (2000) Inbreeding depression and conservation biology. Annu Rev Ecol Syst 31:139-162. https://doi.org/10.1146/annur ev.ecolsys.31.1.139

Hong DY (1997) Notes on Paeonia decomposita Hand.-Mazz. Kew Bull 52:957-963. https://doi.org/10.2307/4117822

Hong DY (2010) Peonies of the world: taxonomy and phytogeography. Royal Botanical Gardens Kew Publishing, Kew \& Missouri Botanical Garden Press, St Louis, London, pp 1-302

Hong DY (2011) Paeonia rotundiloba (DY Hong) DY Hong: a new status in tree peonies (Paeoniaceae). J Syst Evol 49:464-467. https://doi.org/10.111 1/j.1759-6831.2011.00149.x

Hong Y, Liu Q (2006) A study on the pollination biology of Paeonia lactiflora Pall. Guihaia 26:120-124

Hong DY, Pan KY (1999) Taxonomical history and revision of Paeonia sect. Mou$\tan$ (Paeoniaceae). Acta Phytotax Sin 37:351-368 
Hong DY, Pan KY, Turland JN (2001) Paeoniaceae. Flora of China. Science Press and Missouri Botanical Garden Press, Beijing, pp 127-132

Hong DY, Zhou SL, He XJ, Yuan JH, Zhang YL, Cheng FY, Zeng L, Wang Y, Zhang XX (2017) Current status of wild tree peony species with special reference to conservation. Biodivers Sci 25:781-793. https://doi.org/10.17520/biods .2017129

Hu WQ, Lu H, Liu W, Yuan JX, Zhang D (2011) Paternity identification and genetic structure analysis on the wild population in Paeonia lactiflora Pallas (Paeoniaceae). Acta Hortic Sin 38:503-511

Husband BC, Schemske DW (1996) Evolution of the magnitude and timing of inbreeding depression in plants. Evolution 50:54-70. https://doi. org/10.1111/j.1558-5646.1996.tb04472.x

Jing XM, Zheng GH (1999) The characteristiction seed germination and dormancy of four wild species of tree peonies and the bearing on endangerment. Acta Phytophysiol Sin 25:214-221

Jules ES, Rathcke BJ (1999) Mechanisms of reduced Trillium recruitment along edges of old-growth forest fragments. Conserv Biol 13:784-793. https:// doi.org/10.1046/j.1523-1739.1999.97435.x

Keller LF, Waller DM (2002) Inbreeding effects in wild populations. Trends Ecol Evol 17:230-241. https://doi.org/10.1016/S0169-5347(02)02489-8

Latter BDH, Mulley JC, Reid D, Pascoe L (1995) Reduced genetic load revealed by slow inbreeding in Drosophila melanogaster. Genetics 139:287-297

Li HS (2000) Plant physiological and biochemical experimental principles and techniques [M]. Higher Education Press, Beijing

Li K, Zheng BQ, Wang Y, Guo X (2013) Flowering characteristics and breeding system of Paeonia delavayi. J Northeast For Univ 41:63-67

Li K, Zheng BQ, Wang Y (2014) Breeding system and pollination biology of Paeonia delavayi (Paeoniaceae), an endangered plant in the southwest of China. Pak J Bot 46:1631-1642

Lloyd DG, Schoen DJ (1992) Self- and cross-fertlization in plants I. Functional dimensions. Int J Plant Sci 153:358-369. https://doi.org/10.1086/297040

Luo YB, Pei YL, Pan KY, Hong DY (1998) A study on pollination biology of Paeonia suffruticosa subsp. spontanea (Paeoniaceae). Acta Phytotax Sin 36:134-144

O'Grady JJ, Brook BW, Reed DH, Ballou JD, Tonkyn DW, Frankham R (2006) Realistic levels of inbreeding depression strongly affect extinction risk in wild populations. Biol Conserv 133:42-51. https://doi.org/10.1016/j.bioco n.2006.05.016

Oostermeijer JGB, Luijten SH, Nijs JCM (2003) Integrating demographic and genetic approaches in plant conservation. Biol Conserv 113:389-398. https://doi.org/10.1016/S0006-3207(03)00127-7

Schemske DW, Lande R (1985) The evolution of self-fertilization and inbreeding depression in plants 2 empirical observations. Evolution 39:41-52. https://doi.org/10.1111/j.1558-5646.1985.tb04078.x
Schlising RA (1976) Reproductive proficiency in Paeonia californica (Paeoniaceae). Amer J Bot 63:1095-1103. https://doi. org/10.1002/j.1537-2197.1976.tb13194.x

Silva NF, Goring DR (2001) Mechanisms of selfincompatibility in flowering plants Cell. Mol Life Sci 58:1988-2007. https://doi.org/10.1007/PL000 00832

Stebbins GL, Ellerton S (1939) Structural hybridity in Paeonia californica and P. brownii. J Genetics 38:1-36. https://doi.org/10.1007/BF02982164

Turpin RA, Schlising RA (1971) A new method for studying pollen dispersal using iodine 131. Rad Bot 11:75-78. https://doi.org/10.1016/S0033 -7560(71)91466-9

Vere ND, Jongejans E, Plowman A, Williams E (2008) Population size and habitat quality affect genetic diversity and fitness in the clonal herb Cirsium dissectum. Popul Ecol 159:59-68. https://doi.org/10.1007/s0044 2-008-1203-y

Walter JL (1942) Distribution of structural hybrids in Paeonia californica. Am J Bot 29:270-275. https://doi.org/10.1002/j.1537-2197.1942.tb14005.x

Wang SQ, Zhang D (2008) Chromosome inversion heterozygosity in Paeonia decomposita (Paeoniaceae). Caryologia 61:128-134. https://doi. org/10.1080/00087114.2008.10589619

Ward M, Dick CW, Gribel R, Lowe AJ (2005) To self, or not to self: a review of outcrossing and pollen-mediated gene flow in neotropical trees. Heredity 95:246-254. https://doi.org/10.1038/sj.hdy.6800712

Wesselingh RA (2007) Pollen limitation meets resource allocation: towards a comprehensive methodology. New Phytol 174:26-37. https://doi.org/10. 1111/j.1469-8137.2007.01997.x

Willis JH (1999) The roles of genes of large effect on inbreeding depression in Mimulus guttatus. Evolution 53:1678-1691. https://doi.org/10.2307/26404 31

Yang Y, Luo JT, Zhang BF, Song HX, Liu GL, Zeng XL (2015) Studies on floral characteristics and breeding system of Paeonia decomposita. J Plant Resour Environ 24:97-104

Zhang YL, Han XY, Niu LX, Zhang J, He LX (2015) Analysis of fatty acid in seed oil from nine wild peony species. J Chin Cereals Oils Assoc 30:72-79

Zhou SL, Hong DY, Pan KY (1999) Pollination biology of Paeonia jishanensis THong \& W Z Zhao (Paeoniaceae), with special emphasis on pollen and stigma biology. Bot J Linn Soc 130:43-52. https://doi.org/10.1006/ bojl.1998.0239

\section{Publisher's Note}

Springer Nature remains neutral with regard to jurisdictional claims in published maps and institutional affiliations.

\section{Submit your manuscript to a SpringerOpen ${ }^{\odot}$ journal and benefit from:}

- Convenient online submission

- Rigorous peer review

- Open access: articles freely available online

- High visibility within the field

- Retaining the copyright to your article

Submit your next manuscript at $\boldsymbol{\nabla}$ springeropen.com 